24. Global Structure of Microwave-Assisted Flash-Extracted Sugar Beet Pectin / Fishman M. L., Chau H. K., Cooke P. H., Hotchkiss Jr. A. T. // Journal of Agricultural and Food Chemistry. 2008. Vol. 56, Issue 4. P. 1471-1478. doi: https://doi.org/10.1021/jf072600o

25. Pectin, a versatile polysaccharide present in plant cell walls / Voragen A. G. J., Coenen G.-J., Verhoef R. P., Schols H. A. // Structural Chemistry. 2009. Vol. 20, Issue 2. P. 263-275. doi: https://doi.org/10.1007/s11224-009-9442-z

26. Kurita O., Fujiwara T., Yamazaki E. Characterization of the pectin extracted from citrus peel in the presence of citric acid // Carbohydrate Polymers. 2008. Vol. 74, Issue 3. P. 725-730. doi: https://doi.org/10.1016/j.carbpol.2008.04.033

27. Ultrasound-assisted extraction of pectins from grape pomace using citric acid: A response surface methodology approach / Minjares-Fuentes R., Femenia A., Garau M. C., Meza-Velázquez J. A., Simal S., Rosselló C. // Carbohydrate Polymers. 2014. Vol. 106. P. 179-189. doi: https://doi.org/10.1016/j.carbpol.2014.02.013

Досліджено дію препаратів антимікробної дї Байкал ЕМ-1, 0,5\%-ний розчин лимонної, 0,2\%-ний бензойної, 0,05\%-ний сорбінової кислот, 0,5:0,5\% розчин вітамінів С та Р (аскорутин) - на збереженість та якість капусти броколі. Встановлено, що препарати антимікробної дї сприяють подовженню строку зберігання капусти броколі на 5-20 діб залежно від гібриду. Обробка препаратами зменшуе втрати за добу у 1,2-3,0 рази, забезпечує вихід тварної продукцї 76,8-86,2\%.

Обробка капусти броколі препаратами антимікробної дї, особливо аскорутином, забезпечують вміст сухої речовини в 1,1-2,6 рази більше, ніж у контролі, сприяе зниженню інтенсивності витрачання сухих розчинних речовин та вітаміну С. У кінці зберігання вміст загального иукру та дисахаридів на рівні з контрольним варіантом, або перевищує його вміст відповідно в 1,2 та 1,5-2,0 рази. Більше у варіантах з кислотами та аскорутином. Вміст моносахаридів зберігається на початковому рівні. Втрати маси за рахунок випаровування води більше в 1,3-1,8 рази.

Байкал ЕМ-1 та аскорутин краще, ніж інші препарати стримують інтенсивність розвитку хвороботворних мікроорганізмів на 10-15 діб. Аскорутин забезпечує за тривалого зберігання менші на 0,8-2,2\% втрати маси від хвороб та фізіологічних розладів і на 4,1-7,6 \% більший вихід товарної продукцї. Більш активно пригнічує розвиток хвороботворних мікроорганізмів на капусті броколі аскорутин, лимонна, сорбінова та бензойна кислоти. Проте, від фізіологічних розладів під час зберігання препарати не захищають плоди. Спосіб оброблення капусти броколі препаратами антимікробної дії перед зберіганням дозволяє використання антисептиків - Байкал ЕМ-1, 0,5\%-ний розчин лимонної, 0,2\%-ний бензойної, 0,05\%-ний сорбінової кислот, 0,5:0,5\% розчин вітамінів С та Р (аскорутин) - для післязбиральної обробки овочевої сировини. У розробці нових, низъковитратних, екологічно чистих $і$ доступних технологій ие є важливим прийомом

Ключові слова: якість капусти броколі, антисептики, строк зберігання, компоненти хімічного скаладу, збереженість
UDC 35.356:631.563

DOI: $10.15587 / 1729-4061.2018 .140064$

\section{RESEARCH INTO PRESERVATION OF BROCCOLI DEPENDING ON THE TREATMENT WITH ANTIMICROBIC PREPARATIONS BEFORE STORAGE}

L. Pusik

Doctor of Agricultural Sciences, Professor Department of technologies of processing of food production named after T. P. Yevsiukova**

V.Pus i k

Doctor of Agricultural Sciences, Professor*

N. L y u b y m o v a

Doctor of of Technical Sciences, Professor*

E-mail: nina.lioubimova@gmail.com

V. B o nd are n k o $\mathrm{PhD} * * *$

L. G a e v a y a

Teacher***

*Department of Agrotechnology and Ecology**

**Kharkiv Petro Vasylenko

National Technical University of Agriculture

Alchevskykh str., 44, Kharkiv, Ukraine, 61000 $* * *$ Department of fruit and vegetable and storage

Kharkiv National Agrarian University named after V. V. Dokuchayev

township Dokuchaevsky, Kharkiv district, Kharkiv region, Ukraine, 62483
1. Introduction

Fresh vegetables have a limited storage period even under conditions of optimum temperature and humidity. The reasons are a large natural loss of weight and the loss due to diseases and physiological disorders. In addition, vegetables lose freshness and consistency. They also lose content of components of their chemical composition. Fresh fruits 
and vegetables lose $20-25 \%$ of their volume due to diseases even under optimal storage conditions [1]. It is necessary to perform post-harvest treatment of vegetables and fruits with chemicals to overcome losses and, as a consequence, to increase storage period. We can divide chemicals into groups by their action: antiseptics - they act against changes caused by a vital activity of microorganisms; antioxidants - they prevent chemical changes; emulsifiers-substances - they prevent physical changes [2].

There is a need to find new substances of natural origin under existing conditions of ecological deterioration, when various negative environmental factors affect the environment and the human body. Treatment with antiseptics increases the yield of commercial products and maximizes taste and nutritional and therapeutic properties of broccoli.

Given the above, the development of a technology for storing broccoli with the use of antimicrobial substances, which should be environmentally friendly and simple in implementation, is essential and relevant.

\section{Literature review and problem statement}

The aim of treatment of fruit and vegetable products by chemicals of various actions is increasing the retaining capacity and the yield of commercial products at the end of storage. Growers treated brussels sprouts with a benzimidazole solution for long-term preservation of good quality and green color, and then they stored it under light in a modified atmosphere, which contained $7 \%$ of $\mathrm{CO}_{2}$ and $14 \%$ of $\mathrm{O}_{2}$. They treated heads of cabbage, cauliflower, celery, broccoli and lettuce with aqueous solutions of $\mathrm{N}^{6}$-benzylidene (an inhibitor of plant tissue senility, which reduces intensity of respiration) on a day before harvesting or before storage. Products remained untreated 1.5 times longer and contained more chlorophyll by $2-4$ times [3]. Tissues lose important components of a chemical composition - sugars, organic acids, phenolic substances during respiration. The lower respiration intensity of fruits, the better is their quality and nutritional value. But there were no changes in components of a chemical composition in the above studies.

Growers treated tomatoes with solutions of boric acid, potassium permanganate and calcium chloride before storage in polyethylene bags. Their storage life increased in 3 times due to the reduction of natural losses. Treated fruits preserved a good consistency, acquired an attractive color and aroma and contained more vitamin $\mathrm{C}$ throughout the entire period [4]. The action of antiseptics consists in the fact that chemicals combine with proteins of membranes of microorganisms, and act on cells toxically, which causes their death. However, chemicals do not protect fruits from physiological disorders during storage.

Treatment of the inner part of plastic bags and packaging paper with essential oils of Siberian fir and cinnamon for storage of beet, cabbage, onions, potatoes, carrots and strawberries prevented development of fungal diseases of products $[5,6]$. In addition, it is possible to use essential oils of oregano, thyme, ash, marjoram, lavender, rosemary, wormwood and mint of marsh against Botrytis cintrea, Fusarium solani var. [7]. Thyme essential oil and essential oil of savory maintained a bunch of table grapes clean from Penicillium digitatum and Rhizopus stolonifer for 60 days of storage [8]. Treatment with chitosan reduced a damage of gray rot of table sorts of grapes by 2 times [9] and increased the storage life of strawberry and lettuce [10]. Oil of Siberian fir, oils of oregano, thyme, ash tree, marjoram, lavender, rosemary, wormwood and marsh mint contain tannins, ascorbic acid, tocopherols, tannins, phenolcarboxylic acids, phytoncides, alkaloids and flavonoids. All of them have bactericidal properties; they suppress staphylococci and rod bacterium microorganisms.

Bacteria Bacillus amyloliquefaciens and yeasts Pichia guilliermondii, Candida guilliermondii, C. oleophila and Rhodosporidium paludigenum protected tomatoes from gray rot before storage [11]. There is information on the treatment of potato tubers with isolates of Bacillus spp before storage, which made it possible to keep tubers clean from a rotten pathogen up to 8 months [12]. The use of Aureobasidium pullulans PL5 reduced loss of plums and peaches from brown rot, and apples - from blue and gray molds by 2 times [13].

We should note that the use of microbial preparations almost does not require changes in the technology of storage of vegetables. The main thing is to take into account their composition. Preparations in their composition are living microorganisms with biologically active products of their livelihood. Therefore, microbial preparations can lose their properties without observance of the obligatory conditions of their storage and application. Biological means do not eliminate harmful species completely; they only reduce harmfulness of microorganisms to an acceptable level. Researchers consider the biological method as a component of the control of harmful organisms.

Growers effectively used Cryptococcus laurentii and hay bacterium against Rhizopus stolonifer, gray and blue molds and wet rot at storage of peaches and nectarines [14]. Authors give information on treatment with Kloeckera apiculata yeast against Penicillium expansum, Botrytis cinerea and Monilinia fructicola [15]. Yeast of Pichia caribbica provided inhibition of expansion of wet rot and an increase in activity of peroxidase and catalase in fruit cells [16].

Paper [17] proposes extracts of plants such as Borago officinalis, Orobanche crenata, Plantago coronopus, Plantago lanceolata, Sanguisorba minor, Silene vulgaris, Sonchus asper, Sonchus oleraceus and Taraxacum officinale for post-harvest treatment of fruits and vegetables [17].

Cryptococcus laurentii and hayloaf effectively protected peaches and nectarines against Rhizopus stolonifer, gray and blue mold and wet rot during storage [18-20]. Authors of work [21] used Kloeckera apiculata yeast against Penicillium expansum, Botrytis cinerea and Monilinia fructicola [21]. Yeast of Pichia caribbica inhibited expansion of wet rot and increased activity of peroxidase and catalase in fruit cells in study [22]. Such treatment stimulates protective reactions of fruits, which extends their storage time by $20 \%$. It reduces losses caused by microbiological damage by $50 \%$. However, the disadvantage of the method is a significant increase in the cost of products.

Treatment freshly cut cabbage with a $1 \%$ solution of citric acid kept its freshness for 22 days at a temperature of $0 \ldots 5^{\circ} \mathrm{C}$ and prevented its browning in a place of a cut [18]. Studies on different fruits confirmed effectiveness of a use of acetic acid, peracetic, salicylic, jasmine acids and methylazasmonate against rot and mold [19, 20]. Zucchini treated with solutions of polyamines, such as putrescine, spermidine and spermine for 12 days at a storage temperature of $0{ }^{\circ} \mathrm{C}$ had less weight loss than control ones, they preserved their color and firm consistence of a pulp [21]. Citric acid slows expansion of all microorganisms especially; it prevents development of bacteria by reducing of $\mathrm{pH}$ of cellular juice. It also exhibits 
antioxidant action. There were no studies of the antimicrobial properties of such preparations for post-harvest treatment of broccoli before storage.

Treatment of cherries with a $10 \%$ ethanol solution heated to $60{ }^{\circ} \mathrm{C}$ inhibited expansion of spores of Penicillium expansum and Botrytis cinerea during storage [22]. Strawberry losses caused by grey mold decreased at immersion in water at a temperature of $55^{\circ} \mathrm{C}$ and $60{ }^{\circ} \mathrm{C}$ for 30 seconds [23]. Authors of work [24] submerged peaches and nectarines in water of a temperature of $48{ }^{\circ} \mathrm{C}$ before storage to control expansion of brown rot (Monilinia laxa). Peaches - for 12 minutes and nectarines - for 6 minutes. This reduced disease losses in 10 times and maintained the quality of fruits [24]. Immersion of peaches in water of $37^{\circ} \mathrm{C}$ and their subsequent treatment with Cryptococcus laurentii reduced losses caused by blue mold and wet rot [25]. Sorbic acid and benzoic acids act against mold fungi and yeast and partly bacteria [4].

We can note that scientific information on the use of antimicrobial preparations for preservation and quality of broccoli is not sufficient. Because there are no studies on the subject. Treatment of fruit and vegetable products with antimicrobial preparations before storage has a number of disadvantages. Namely, it does not protect fruits from physiological disorders during storage. There are no changes in components of a chemical composition in the above studies carried out. Biological means do not eliminate microorganisms completely, they only reduce harm to an acceptable level. The disadvantage of the method is a significant increase in the cost of production.

Therefore, it is important to investigate an effect of antimicrobial preparations on weight loss, changes in components of a chemical composition of broccoli, microorganism affection and physiological disorders during storage.

\section{The aim and objectives of the study}

The aim of this study was to investigate an effect of antimicrobial preparations on preservation and quality of broccoli to determine duration of the storage life of broccoli in dependence on a preparation.

We solved the following tasks to achieve the objective:

- determination of natural mass loss during storage;

- study on affection of broccoli with diseases and physiological disorders;

- investigation of a change of components of a chemical composition during storage of broccoli;

- conduction of a comparative estimation of preservation of broccoli in dependence on a type of antimicrobial preparation.

\section{Materials and methods to study preservation of quality of broccoli and chemical and organoleptic parameters}

We conducted the research with late ripening hybrids of broccoli (Ironman $F_{1}$, Agassi $F_{1}$, and Beaumont $F_{1}$ ). The method of growing was seedlings (we planted seedlings with 4-5 actual leaves). The method of placement of plants a tape one with a scheme of placement $(40+100) \times 50 \mathrm{~cm}$. The registration area in the experiment with broccoli was $50 \mathrm{~m}^{2}$, the repetition of the experiments was three times. The placement of options was systematic. The experiment was a one-factor experiment. We collected broccoli when heads acquired technical ripeness, size and density, which are characteristic for a certain hybrid. The diameter of a head of broccoli was not less than $4 \mathrm{~cm}$ according to the standard. We collected broccoli twice because it forms a second harvest on side heads after cutting of central heads. Ironman $F_{1}$ is a hybrid of broccoli for fresh processing and consumption. The color of heads is saturated blue-green, heads are highly dome-shaped, dense and heavy. Agassi $F_{1}$ is a universal hybrid of broccoli suitable for freezing and processing. Heads are of attractive light green color, it has very homogeneous inflorescences, they are medium-high and of high standard. Beaumont $F_{1}$ is a universal hybrid of broccoli. Head mass is up to $2.5 \mathrm{~kg}$. Heads are of fine-grained structure, they are round, aligned and dark green. They have a very attractive appearance and a unique taste and they do not lose it. The hybrid is suitable for processing.

Paper [26] presents materials and methods for the study on preservation of the quality of broccoli and chemical and organoleptic parameters in more detail [26].

\section{Results of study into preservation of broccoli}

We established that the treatment of broccoli with antimicrobial preparations before storage with subsequent packaging in plastic bags contributed to their better preservation. On average, during the years of research (Fig. 1), natural mass losses in variants with the use of Baikal EM-1 preparation were: for Ironman $F_{1}$ hybrid $-4.5 \%$ for 35 days of storage, for Agassi $F_{1}-4.7 \%$ for 30 days, for Beaumont $F_{1}-3.4 \%$ for 35 days; losses were slightly lower with the use of citric acid: $4.0 \%, 4.3 \%$ and $3.0 \%$ for 35 days, respectively; with the use of sorbic acid: for Ironman $F_{1}-2.4 \%$ for 30 days of storage, for Agassi $F_{1}-3.0 \%$ for 25 days, for Beaumont $F_{1}-2.2 \%$ for 35 days.

With the use of benzoic acid, natural losses were: for Ironman $F_{1}-3.0 \%$ for 35 days, Agassi $F_{1}-3.3 \%$ for 25 days and for Beaumont $\mathrm{F}_{1}-2.4 \%$ for 35 days of storage. Application of ascorutin contributed to prolonging the storage life of broccoli hybrids - Ironman $F_{1}$ and Beaumont $F_{1}$ up to 45 days, Agassi $F_{1}$ up to 40 days. The natural weight loss was 4.1, 3.5 and $4.6 \%$, respectively, during this period (Fig. 1).

The intensity of the affection of broccoli with diseases and physiological disorders during storage depends not only on weather conditions of the growing season, but also on the treatment of products with antimicrobial preparations before packaging. We established that the treatment of broccoli heads with antimicrobial preparations inhibited expansion of microorganisms and thus prolonged duration of its storage. The first signs of the affection and physiological disorders in Ironman $\mathrm{F}_{1}$ hybrid heads treated with Baikal EM-1 and ascorutin preparations appeared 15 days later (on day 35) than in the control variant (Fig. 2). Losses were $11.9 \%$ and $6.4 \%$, respectively.

At treatment with citric acid, we observed first injured heads on day 30 of storage $-9.8 \%$; with the use of sorbic acid and benzoic acid, we recorded the first signs of the affection as in the control version - on day 20. The losses were smaller by 1.1 and 1.9 times, respectively.

At further storage, we observed less rapid expansion of diseases and physiological disorders in the variants with Baikal EM-1 and ascorutin preparations: there were product losses of about $20 \%$ on days 45 and 50 of storage, respectively. 


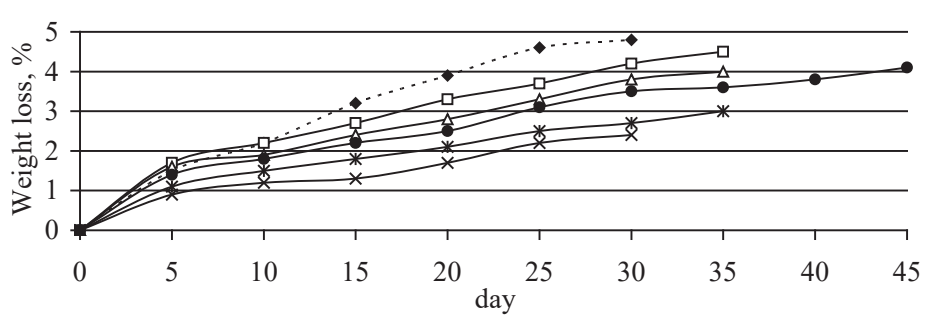

a
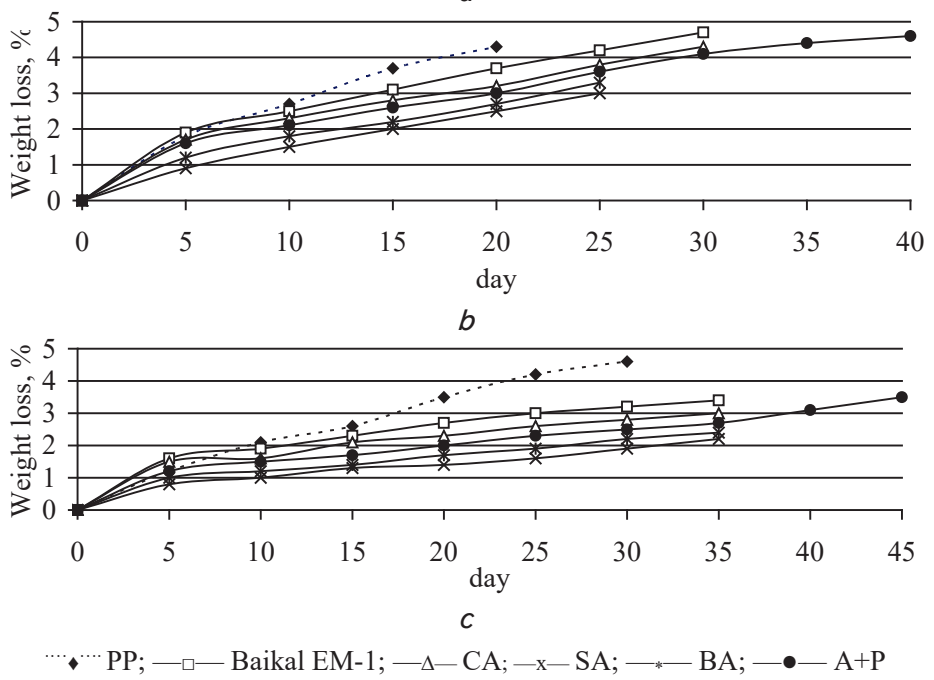

Fig. 1. Dynamics of natural mass loss of heads of broccoli hybrids in dependence on the treatment with preparations of antimicrobial action, \%: $a$-Ironman $F_{1}, b-$ Agassi $F_{1} ; c-$ Beaumont $F_{1}$
The variance analysis established that the effect of treatment of broccoli with antimicrobial preparations on total natural losses was $74.7 \%$.

Natural losses per day were significantly lower in the variants with the use of antimicrobial preparations than without such treatment $\left(\mathrm{LSD}_{05}=\right.$ $=0.01-0.02 \%)$. Results fluctuated within $0.11-0.15 \%$ for Agassi $F_{1}$, within $0.07-0.13 \%$ for Ironman $F_{1}$, and results for Beaumont $F_{1}$ hybrid were somewhat smaller - within $0.05-0.10 \%$. The treatment with preparations reduced losses per day for Ironman $F_{1}$ by $1.2-2.1$ times, for Agassi $F_{1}-$ by $1.3-1.9$ times and for Beaumont $F_{1}$ - by 1.5-3.0 times depending on the preparation compared with the variants without treatment. The share of preparation effect was $58.0 \%$.

We found that losses of products due to diseases and physiological disorders depends by $11.7 \%$ on the treatment with a preparation (factor A), by $3.7 \%$ on characteristics of a hybrid (factor B) and by $27.7 \%$ on the combined effect of these factors. These fluctuations range within $10.5-18.4 \%$ for Ironman $F_{1}$, within $10.2-17.6 \%$ for Agassi $F_{1}$, and from 10.5 to $18.4 \%$ for Beaumont $F_{1}$ depending on the preparation (Table 1).

The yield of products at the end of storage fluctuated, on average, within $76.8-86.9 \%$ for Ironman $F_{1}$ over the years of research, in dependence on a preparation, for Agassi $F_{1}-78.5-87.6 \%$, and for Beaumont $F_{1}$ - from 78.5 to $88.2 \%$.
The use of ascorutin delayed expansion of pathogenic microorganisms for Agassi $F_{1}$ hybrid. The first signs of the affection appeared on them 15 days later (on 30th day) than in the control variant, and losses were $6.1 \%$.

The treatment with Baikal EM-1 and citric acid increased resistance to diseases. The first signs of damage appeared 10 days later (on day 25) than in the control variant and were 8.0 and $9.7 \%$, respectively.

With the use of sorbic and benzoic acids, diseases appeared 5 days later than in the control variant, and losses were $3.7 \%$ and $3.4 \%$, respectively. This hybrid is unstable to disease during storage, so losses of products in the variants with the use of citric acid, sorbic acid and benzoic acid reach about $20 \%$ or more after 5-10 days. Diseases on the heads treated with Baikal EM-1 and ascorutin developed less intensively.

The treatment of the heads of Beaumont $F_{1}$ hybrid with Baikal EM-1 and ascorutin increased the period of disease development for 10 days. The first signs of the affection appeared on day 35 and losses were 10.2 and $4.6 \%$, respectively. The treatment with citric acid delayed manifestation of diseases for 5 days.

The first losses appeared on day 30 and was $8.0 \%$. The first signs of a presence of diseases of products treated with sorbic acid and benzoic acid appeared on day 25 , as well as in the control variant. The losses were $3.5 \%$ and $2.7 \%$, respectively. Diseases of broccoli treated with ascorutin developed less intensively at further storage.
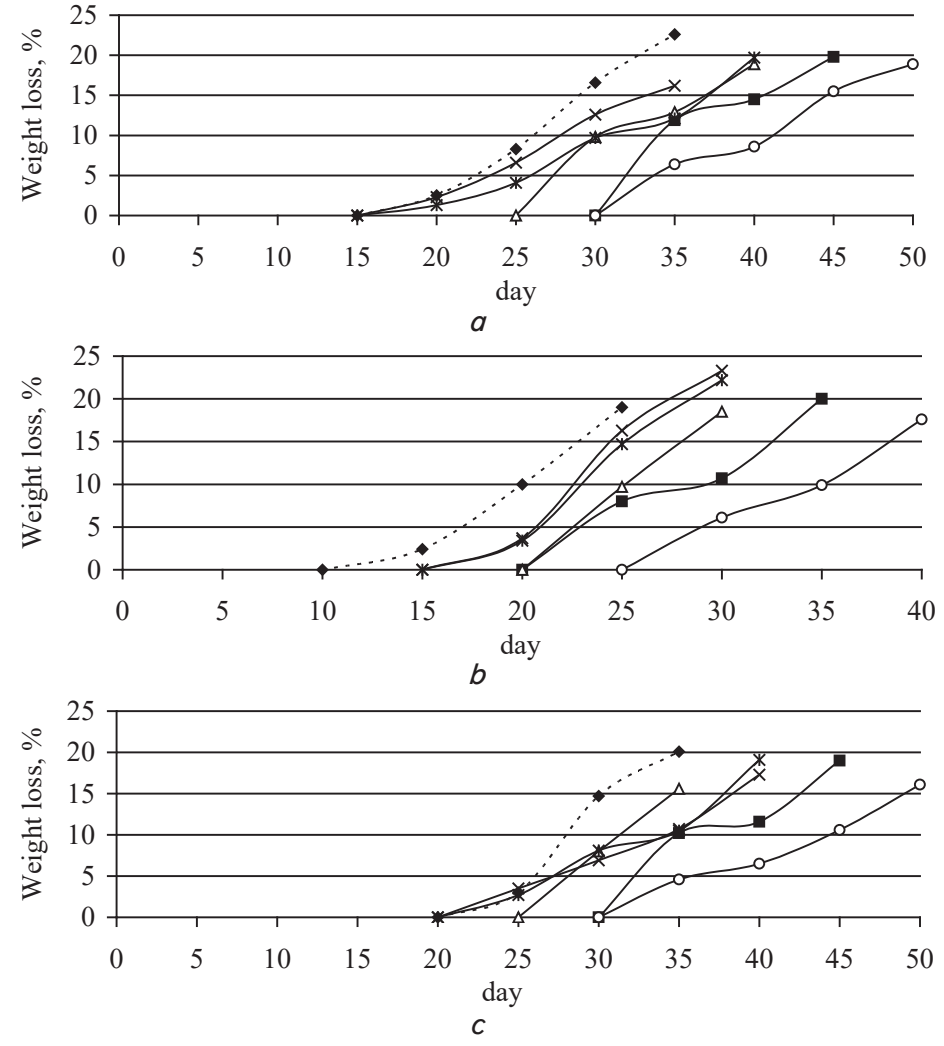

$\mathrm{PP} ;-\square-$ Baikal EM-1; $-\Delta-\mathrm{CA} ;-\mathrm{x}-\mathrm{SA} ;-*-\mathrm{BA} ;-\bullet-\mathrm{A}+\mathrm{P}$

Fig. 2. Dynamics of mass loss of heads of broccoli hybrids due to diseases and physiological disorders in dependence on the treatment with antimicrobial preparations, \%: $a-$ Ironman $F_{1} ; b-$ Agassi $F_{1}$; $c-$ Beaumont $F_{1}$ 
Table 1 We established that the content

Preservation of broccoli depending on the treatment with antimicrobial preparations (average over the years of studies)

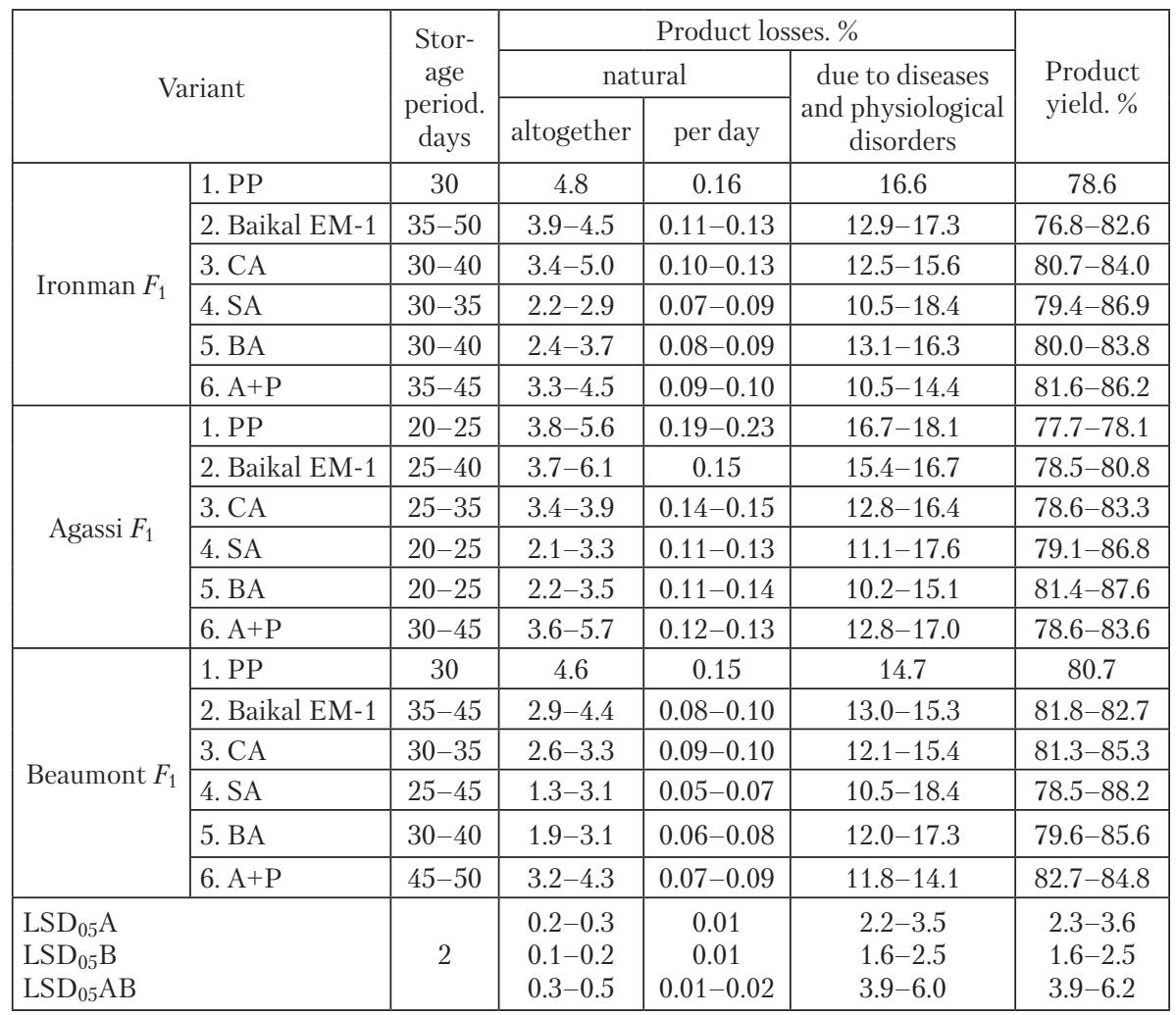

Note: PP - storage of unprocessed cabbage. processing: $C A$ - citric acid; $S A$ - sorbic acid; BA benzoic acid; $A+P-$ ascorutinum

When studying the effects of antimicrobial preparations on the phytosanitary state of broccoli, we found that pathogenic microorganisms developed on untreated heads of broccoli more intensively at the beginning of storage: up to $20 \%$, they were affected to a high degree from day 30 . The number of injured heads remained the same for all variants, but we did not find heads affected in a high degree among the variants with the use of Baikal EM-1, citric acid and ascorutin. Phytopathogenic organisms developed less intensively on washed with ordinary water heads and treated with sorbic acid and benzoic acid than on untreated ones - by $10 \%$.

We found no heads affected by diseases to a high degree in the middle of storage among the variants with the use of ascorutin. There were $10 \%$ of the heads affected to a high degree in the variant with citric acid.

Diseases and disorders affected half of the heads to a high degree in all other cases. The total number of injured heads was $40 \%$ in the middle of storage.

At the end of storage, the number of broccoli-headed affected with diseases was more than half, and in variants without treatment, with washed heads, it was $70 \%$ with the application of Baikal EM-1 and citric acid. $30 \%$ of them were affected by diseases to a high degree. The intensity of disease development in the variants with the use of sorbic, benzoic acid and ascorutin was less and it was $60 \% .20 \%$ of the heads were affected to a high degree.

Treatment of broccoli with antimicrobial preparations before storage and package by $40 \mu \mathrm{m}$ thick film contributed to preservation of components of the chemical composition. of dry matter in broccoli was higher in the variants with the use of antimicrobial preparations than in the control one at the end of storage. Ironman $F_{1}$ hybrid with the use of Baikal EM-1 preparation and citric acid lost 1.3 times less dry matter in 35 days of storage than the control variant in 30 days, in average for the years of research. The losses were less by 2.5 times for 30 days at the use of sorbic acid; by 1.8 times for 35 days in the version with benzoic acid; by 1.5 times for 45 days with ascorutin than in the control variant.

Agassi $F_{1}$ hybrid lost $3.1 \%$ of dry matter when using Baikal EM-1 in 30 days of storage, while in the control variant $-3.2 \%$ in 20 days.

The losses were less by $1.1 \mathrm{ti}$ mes for 30 days of storage in the variant with treatment with citric acid. Treatment with sorbic and benzoic acids reduced the losses by 1.6 and 1.5 times, respectively, for 25 days. Application of ascorutin - reduced the losses of dry matter by 1.1 times than in the control version for 40 days of storage.

The loss of dry matter in Beaumont $F_{1}$ hybrid with the use of Baikal EM-1, citric, sorbic, and benzoic acids was less by 1.6-2.6 times for 35 days of storage than in the control variant for 30 days. The loss of dry matter was less than 1.8 times for 45 days of storage at application of ascorutin.

The variance analysis found that the treatment with antimicrobial preparations ( $\mathrm{LSD}_{05}=2$ days) influenced the storage life of broccoli significantly. It extended it depending on the hybrid to 50 days. We established that the application of antimicrobial preparations made possible to lose, on average, by 1.1-1.4 times less mass at the expense of dry matter over the years of research than in the control version. Depending on a preparation, these losses were $52.5-72.0 \%$ for Ironman $F_{1}, 56.3-73.1 \%$ for Agassi $F_{1}$, and $50.9-69.2 \%$ for Beaumont $F_{1}$ (Table 2).

The mass losses were significantly lower due to dry matter during $2011-2012\left(\operatorname{LSD}_{05}=10.7-16.3 \%\right)$ with the use of Baikal EM-1 and ascorutin preparations. Due to the evaporation of moisture, on average, weight losses during the years of research were $28.0-47.5 \%$ for Ironman $F_{1}, 26.9-43.7 \%$ for Agassi $F_{1}$, and $30.8-49.1 \%$ for Beaumont $F_{1}$ depending on the preparation, which was larger than the control variant by 1.2-1.9 times (Table 2).

Preparations of antimicrobial action inhibited losses of dry soluble substances in broccoli due to reducing of intensity of respiration. In average, during the years of research, the treatment with preparations inhibited losses of dry soluble substances in Ironman $F_{1}$ hybrid by $1.2-1.7$ times, in Agassi $F_{1}-$ by $1.2-1.9$ times, in Beaumont $F_{1}$ by $1.1-1.5$ times compared to the variant without treatment. 
Table 2 significantly higher content $\left(\mathrm{LSD}_{05}=0.2 \%\right)$ of

Structure of natural losses of mass of broccoli during storage depending on the treatment with antimicrobial preparations

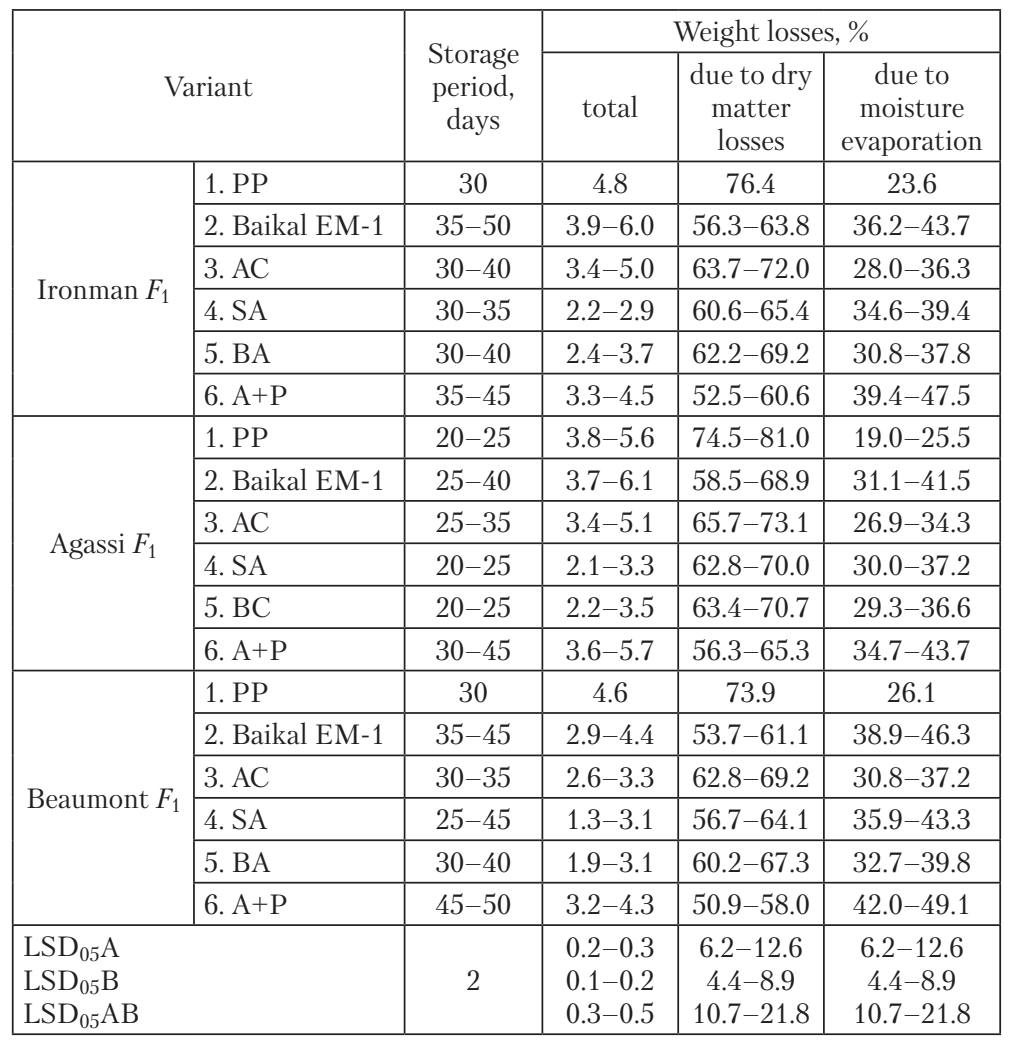

disaccharides with the use of acids and ascorutin and in Agassi $F_{1}$ with the use of benzoic acid.

At the end of storage, the content of total sugars (Table 3 ) decreased by $0.6-1.1 \%$ compared with the initial one for Ironman $F_{1}$, by $0.5-0.9 \%$ for Agassi $F_{1}$, by $0.5-0.8 \%$ for Beaumont $F_{1}$, depending on the preparation. Its content ranged within $2.3-2.8 \%$ for Ironman $F_{1}$, within $2.3-2.7 \%$ for Agassi $F_{1}$, within $2.0-2.3 \%$ for Beaumont $F_{1}$ depending on the preparation. The content of total sugar was significantly higher $\left(\mathrm{LSD}_{05}=0.2 \%\right)$ in Ironman $F_{1}$ and Beaumont $F_{1}$ hybrids in the variants with acids and ascorutin, in Agassi $F_{1}$ - with sorbic and benzoic acids.

The content of total sugar varied within 2.3$2.8 \%$ for Ironman $F_{1}$, within $2.3-2.7 \%$ for Agassi $\mathrm{F}_{1}$, within $2.0-2.3 \%$ for Beaumont $F_{1}$ depending on the preparation. It was significantly higher $\left(\mathrm{LSD}_{05}=0.2 \%\right.$ ) in Ironman $F_{1}$ and Beaumont $F_{1}$ hybrids in the variants with acids and ascorutin, in Agassi $F_{1}$ - with sorbic and benzoic acids.

The content of monosaccharides in broccoli was mainly at the initial level at the end of storage. However, the amount of monosaccharides decreased compared with the initial level by $0.2 \%$ in Ironman $F_{1}$ and Beaumont $F_{1}$ in the variants with Baikal EM-1 and ascorutin. On average, over the years of research, monosaccharide content was within1.6-2.0\% depending on the hybrid and the preparation.
The content of total sugar in broccoli in the middle of storage (10-25 days) over the years of research was higher in the variants with the use of antimicrobial preparations.

The content of total sugar was significantly higher $\left(\operatorname{LSD}_{05}=0.3 \%\right)$ in the variants with the use of citric acid, benzoic acid, sorbic acid and ascorutin.

On average, over the years of research (Table 3), in the variants with preparations, the content of total sugars in the middle of storage decreased by $0.3-0.6 \%$ for Ironman $F_{1}$, by $0.4-$ $0.6 \%$ - for Agassi $F_{1}$, by $0.2-0.5 \%$ - for Beaumont $F_{1}$, depending on the preparation. The content of monosaccharides was almost unchanged from the initial one, it was also higher in the variants with application of preparations and varied in the range of $1.7-2.1 \%$ depending on the hybrid, it was significantly higher $\left(\mathrm{LSD}_{05}=0.2 \%\right)$ in the variants with the use of sorbic acid.

The content of disaccharides decreased by $0.4-0.6 \%$ in the variants with antimicrobial preparations compared with the initial one in the middle of storage. This content exceeded the control index and fluctuated within $0.6-1.0 \%$ depending on the hybrid and the preparation. Ironman $F_{1}$ had
Dynamics of sugar contents in broccoli depending on the treatment with antimicrobial preparations, \% (average for 2011-2013)

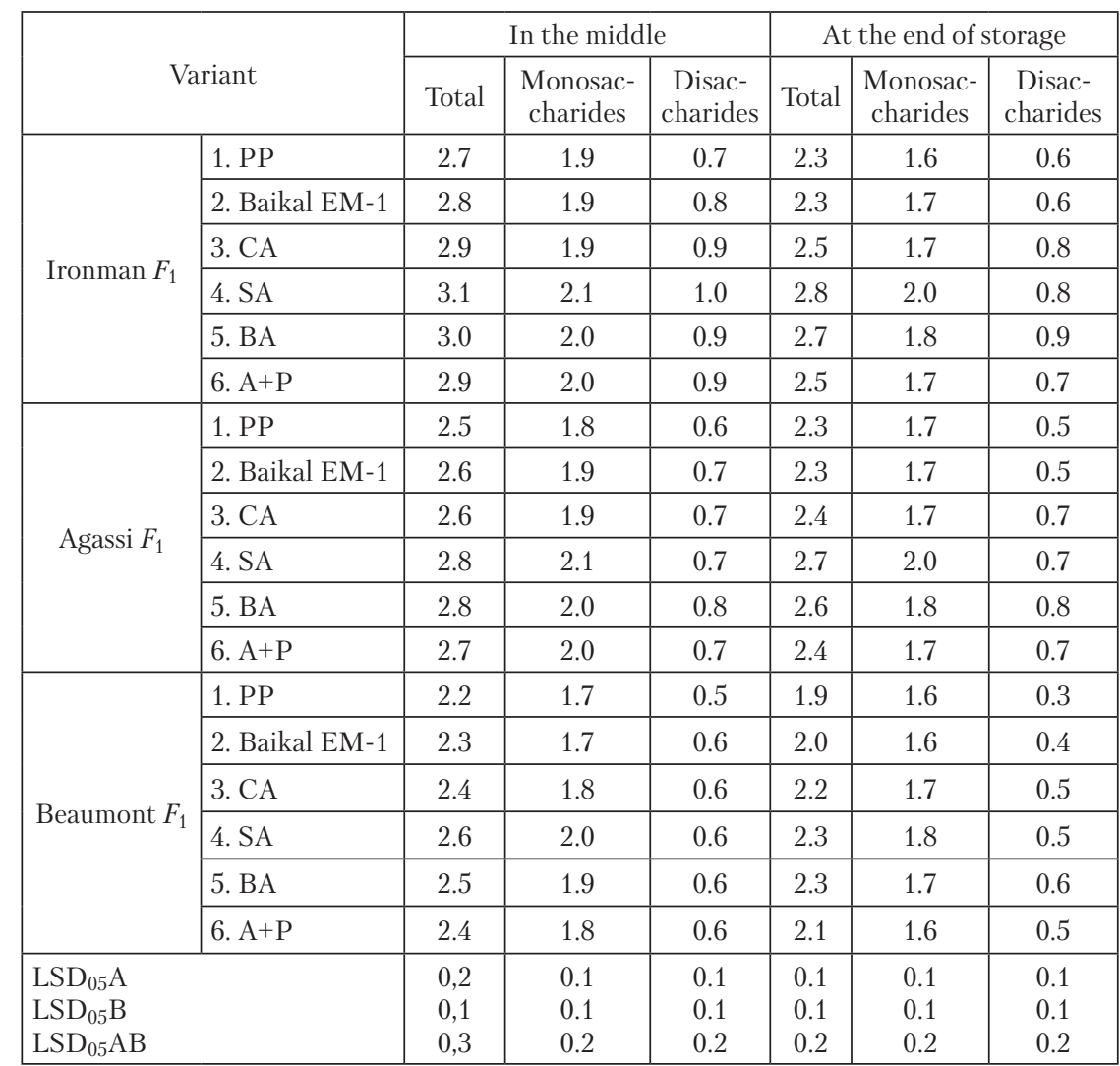

Table 3 
The content $\left(\mathrm{LSD}_{05}=0.2 \%\right)$ was significantly higher in the variants with sorbic and benzoic acids in Ironman $F_{1}$ and with the use of sorbic acid in Agassi $F_{1}$ and Beaumont $F_{1}$. The number of disaccharides decreased in the variants with the use of antimicrobial preparations by $0.5-0.8 \%$ compared with the beginning of storage in Ironman $F_{1}$ and Agassi $F_{1}$ and by $0.4-0.5 \%$ in Beaumont $F_{1}$ depending on the preparation. This number was greater than the number in the control variant and it was in the range of $0.6-0.9 \%$ for Ironman $F_{1}, 0.5-0.8 \%$ - for Agassi $F_{1}, 0.4-0.6 \%$ - for Beaumont $F_{1}$. The variants with the use of citric acid, benzoic acid and sorbic acid had significantly higher $\left(\mathrm{LSD}_{05}=0.2 \%\right)$ content of disaccharides (Table 3 ).

The content of vitamin $\mathrm{C}$ increased in broccoli after the treatment with antimicrobial preparations during the first 15 days of storage, as in the control variants. On average, over the years of research in the first 15 days, the content of vitamin $C$ increased by $24.0-28.3 \%$ in Ironman $F_{1}$ at the beginning of storage, by $25.7-29.9 \%$ in Agassi $F_{1}$, and by $25.8-29.7 \%$ in Beaumont $F_{1}$ depending on the preparation. The content of vitamin $\mathrm{C}$ was significantly higher $\left(\mathrm{LSD}_{05}=1.1-2.7 \mathrm{mg} / 100 \mathrm{~g}\right)$ in the variants with the use of citric acid, sorbic acid, benzoic acid and ascorutin. At the end of storage, vitamin $\mathrm{C}$ content decreased to $22.4 \%$ in Ironman $F_{1}$, to $15.5 \%$ in Beaumont $F_{1}$ and to $25.6 \%$ in Agassi $F_{1}$ depending on the preparation.

\section{Discussion of results of studying the preservation of broccoli depending on the type of an antimicrobial preparation}

A decrease in the quality of broccoli during storage is a consequence of complex physiological, biochemical, physical-chemical and microbiological processes accompanied by destruction of organic compounds because of simultaneous occurrence of reactions of hydrolysis, oxidation and polymerization.

Varietal characteristics, chemical composition and a ratio of components of fruit systems, humidity, hydrogen index of the environment, activity of enzymes, and a degree of variance determine direction and intensity of negative processes. A degree of variance provides access of oxygen to cellular organelles by rapid damage and active development of microorganisms, and presence of natural substances that have bactericidal and bacteriostatic effects inhibits the development of microorganisms. In addition, the intensive process of transpiration significantly influences the course of negative processes at storage under traditional technologies.

For this reason, the yield of standard vegetable production is at the level of $76.8-88.2 \%$ after storage using traditional technologies (Table 1 ). The variance analysis determined that the treatment with preparations (factor A) affects the yield of commercial products by $19.0 \%$, the degree of influence of hybrid features (factor B) was $5.7 \%$, the combined effect of these two factors made up $25.7 \%$, an influence of other factors was $49.7 \%$. We found that the treatment with preparations (factor A) affects the yield of commercial products by $19.0 \%$, the degree of influence of hybrid features (factor B) was $5.7 \%$, the combined effect of these two factors was $25.7 \%$, influence of other factors was $49.7 \%$. The natural losses of broccoli heads during storage were significantly lower $\left(\mathrm{LSD}_{05}=0.2 \%\right)$ compared to the control variant.

Active forms of oxygen generated by activation of oxidative stress damage biological membranes, imbalance post-harvest metabolism of fruits and vegetables, increase intensity of respiration and accelerate processes of overripening and aging. Exogenous treatment with substances, which have high antimicrobial and antioxidant properties, provides neutralization of active forms of oxygen, induction of an endogenous system of protection of fruits and prolongation of its action. In view of this, the use of antiseptics for post-harvest processing of vegetable raw materials is an important technique in terms of the development of new, low-cost and affordable technologies for its storage.

Rutin shows high antioxidant activity among other natural antioxidants of phenolic nature that we can use to prolong preservation. It binds free radicals and inhibits a process of the chain reaction of formation of new aggressive radicals. Rutin is an effective inhibitor of peroxide lipid oxidation. An important mechanism of rutin action in biological systems is chelation of metal ions of variable valency. The role of the main synergist of rutin belongs to ascorbic acid (AA). The antioxidant properties of AA are due to the ability to intercept active forms of oxygen (AFO). An important function of AA is restoration of oxidized forms of other low molecular weight antioxidants, and in the first place, phenolic substances. Studies showed that ascorutin inhibits the intensity of development of pathogenic microorganisms better than other preparations. The first signs of damage appeared 10-15 days later. Ascorutin provided $0.8-2.2 \%$ less weight loss caused by disease and physiological disorders at a long storage, and a 4.1-7.6\% higher yield of commercial products.

Substances of antiseptic effect affect development of pathogens of microbiological diseases. They penetrate the cells of bacteria, yeast and mold fungi; they change a structure of the protoplasm and violate metabolic processes in microorganisms, which leads to inhibition of their development and death. As a result, duration of broccoli storage lengthens and losses due to microbiological damage decrease.

A nature and a degree of action of antimicrobial preparations depend on a nature of a substance, its concentration, an amount and a composition of a surface microflora. However, the treatment of vegetables by antiseptics does not slow down the evaporation of water during storage. It is possible to solve the problem by treatment with a coating, which creates a film, in a composition with antiseptics. Such coating makes possible to create a moisture-retaining and gas-permeable film on a surface of a product for each specimen separately. The consequence is the inhibition of biochemical and reducing of expenditure of substances for metabolic processes.

\section{Conclusions}

1. The natural losses per day were significantly lower in the variants with the use of antimicrobial preparations than in the variant without treatment $\left(\mathrm{LSD}_{05}=0.01-0.02 \%\right)$. The natural losses fluctuated within $-0.11-0.15 \%$ for Agassi $F_{1}$, within $0.07-0.13 \%$ for Ironman $F_{1}$, and they were somewhat smaller for the Beaumont $F_{1}$ hybrid - within $0.05-0.10 \%$. The treatment with preparations reduced the losses per day by $1.2-2.1$ times for Ironman $F_{1}$, by $1.3-1.9$ times for Agassi $F_{1}$ and by 1.5-3.0 times for Beaumont $\mathrm{F}_{1}$ depending on the preparation compared with the variants without treatment. The share of the influence of preparations made up $58.0 \%$.

2. Baikal EM-1 and ascorutin inhibit the intensity of development of pathogenic microorganisms better than other preparations. The first signs of the affection appeared 10-15 days later. Ascorutin provided $0.8-2.2 \%$ less of 
weight loss due to diseases and physiological disorders at a long storage, and a 4.1-7.6\% higher yield of commercial products. Ascorutin, citric acid, sorbic acid and benzoic acid inhibited the development of pathogenic microorganisms in broccoli more actively.

3. The treatment of broccoli with antimicrobial preparations, with ascorutin especially, provided a dry matter content in the amount of 1.1-2.6 times greater than in the control variant. It contributed to a decrease in intensity of consumption of dry soluble substances and vitamin $\mathrm{C}$. At the end of storage, the content of total sugars and disaccharides was equal to the level of the control variant, or exceeded its content by 1.2 and 1.5-2.0 times, respectively. The variants with acids and ascorutin had more of them. The content of monosaccharides was at the initial level. The losses of mass due to evaporation of water were larger by 1.3-1.8 times.

4. Preparations of antimicrobial action contributed to lengthening of the storage life of broccoli for 5-20 days depending on the hybrid. The application of Baikal EM-1 and ascorutin contributed to prolonging the storage life for $40-50$ and $45-50$ days, and the yield of commercial products was $76.8-80.8$ and $78.6-86.2 \%$, respectively.

\section{References}

1. Sharma R. R., Singh D., Singh R. Biological control of postharvest diseases of fruits and vegetables by microbial antagonists: A review // Biological Control. 2009. Vol. 50, Issue 3. P. 205-221. doi: https://doi.org/10.1016/j.biocontrol.2009.05.001

2. Pusik L. M. Vpliv pislyazbiralnoyi obrobki plodiv dini na yih zberezhenist // Ovochivnitstvo i bashtannitstvo. 2006. Issue 52. P. 510-518.

3. Murray M. Altered CYP Expression and Function in Response to Dietary Factors: Potential Roles in Disease Pathogenesis // Current Drug Metabolism. 2006. Vol. 7, Issue 1. P. 67-81. doi: https://doi.org/10.2174/138920006774832569

4. Sammi Sh., Masud T. Effect of Different Packaging Systems on Storage Life and Quality of Tomato (Lycopersicon esculentum var. Rio Grande) during Different Ripening Stages // Internet Journal of Food Safety. 2007. Vol. 9. P. 37-44.

5. Byshko N. A., Mashanov A. I., Muchkina E. Ya. Effektivnost ispolzovaniya efirnogo masla Abies sibirica dlya hraneniya ovoschey // Vestnik Krasnoyarskogo gosudarstvennogo universiteta. 2009. Issue 5. P. 169-174.

6. Rodríguez A., Batlle R., Nerín C. The use of natural essential oils as antimicrobial solutions in paper packaging. Part II // Progress in Organic Coatings. 2007. Vol. 60, Issue 1. P. 33-38. doi: https://doi.org/10.1016/j.porgcoat.2007.06.006

7. Daferera D. J., Ziogas B. N., Polissiou M. G. The effectiveness of plant essential oils on the growth of Botrytis cinerea, Fusarium sp. and Clavibacter michiganensis subsp. michiganensis // Crop Protection. 2003. Vol. 22, Issue 1. P. 39-44. doi: https:// doi.org/10.1016/s0261-2194(02)00095-9

8. Study on the Potential Use of Essential Oils for Decay Control and Quality Preservation of Tabarzeh Table Grape / Abdolahi A., Hassani A., Ghosta Y., Bernousi I., Meshkatalsadat M. // Journal of Plant Protection Research. 2010. Vol. 50, Issue 1. P. 45-52. doi: https://doi.org/10.2478/v10045-010-0008-2

9. Effects of Pre- and Postharvest Chitosan Treatments to Control Storage Grey Mold of Table Grapes / Romanazzi G., Nigro F., Ippolito A., DiVenere D., Salerno M. // Journal of Food Science. 2002. Vol. 67, Issue 5. P. 1862-1867. doi: https:// doi.org/10.1111/j.1365-2621.2002.tb08737.x

10. Devlieghere F., Vermeulen A., Debevere J. Chitosan: antimicrobial activity, interactions with food components and applicability as a coating on fruit and vegetables // Food Microbiology. 2004. Vol. 21, Issue 6. P. 703-714. doi: https://doi.org/10.1016/j.fm.2004.02.008

11. Ability of Moderately Halophilic Bacteria to Control Grey Mould Disease on Tomato Fruits / Sadfi-Zouaoui N., Essghaier B., Hajlaoui M. R., Fardeau M. L., Cayaol J. L., Ollivier B., Boudabous A. // Journal of Phytopathology. 2007. Vol. 156, Issue 1. P. $42-52$. doi: https://doi.org/10.1111/j.1439-0434.2007.01329.x

12. Biological Control of the Potato Tubers Dry Rot Caused by Fusarium roseum var. sambucinum under Greenhouse, Field and Storage Conditions using Bacillus spp. Isolates / Sadfi N., Cherif M., Hajlaoui M. R., Boudabbous A. // Journal of Phytopathology. 2002. Vol. 150, Issue 11-12. P. 640-648. doi: https://doi.org/10.1046/j.1439-0434.2002.00811.x

13. Efficacy of the antagonist Aureobasidium pullulans PL5 against postharvest pathogens of peach, apple and plum and its modes of action / Zhang D., Spadaro D., Garibaldi A., Gullino M. L. // Biological Control. 2010. Vol. 54, Issue 3. P. 172-180. doi: https:// doi.org/10.1016/j.biocontrol.2010.05.003

14. Control of postharvest Rhizopus rot of peach by microwave treatment and yeast antagonist / Zhang H., Fu C., Zheng X., Xi Y., Jiang W., Wang Y. // European Food Research and Technology. 2004. Vol. 218, Issue 6. P. 568-572. doi: https://doi.org/10.1007/ s00217-004-0902-9

15. Karabulut O. A., Baykal N. Biological Control of Postharvest Diseases of Peaches and Nectarines by Yeasts // Journal of Phytopathology. 2003. Vol. 151, Issue 3. P. 130-134. doi: https://doi.org/10.1046/j.1439-0434.2003.00690.x

16. Biocontrol of Postharvest Rhizopus Decay of Peaches with Pichia caribbica / Xu B., Zhang H., Chen K., Xu Q., Yao Y., Gao H. // Current Microbiology. 2013. Vol. 67, Issue 2. P. 255-261. doi: https://doi.org/10.1007/s00284-013-0359-9

17. Activity of extracts from wild edible herbs against postharvest fungal diseases of fruit and vegetables / Gatto M. A., Ippolito A., Linsalata V., Cascarano N. A., Nigro F., Vanadia S., Di Venere D. // Postharvest Biology and Technology. 2011. Vol. 61, Issue 1. P. 72-82. doi: https://doi.org/10.1016/j.postharvbio.2011.02.005

18. Manolopoulou E., Varzakas T. Effect of Storage Conditions on the Sensory Quality, Colour and Texture of Fresh-Cut Minimally Processed Cabbage with the Addition of Ascorbic Acid, Citric Acid and Calcium Chloride // Food and Nutrition Sciences. 2011. Vol. 02, Issue 09. P. 956-963. doi: https://doi.org/10.4236/fns.2011.29130

19. Liu W. T., Chu C. L., Zhou T. Thymol and Acetic Acid Vapors Reduce Postharvest Brown Rot of Apricots and Plums // HortScience. 2002. Vol. 37, Issue 1. P. 151-156. 
20. Enhancing disease resistance in peach fruit with methyl jasmonate / Jin P., Zheng Y., Tang S., Rui H., Wang C. Y. // Journal of the Science of Food and Agriculture. 2009. Vol. 89, Issue 5. P. 802-808. doi: https://doi.org/10.1002/jsfa.3516

21. Effect of infiltrated polyamines on polygalacturonase activity and chilling injury responses in zucchini squash (Cucurbita pepo L.)/ Martínez-Téllez M. A., Ramos-Clamont M. G., Gardea A. A., Vargas-Arispuro I. // Biochemical and Biophysical Research Communications. 2002. Vol. 295, Issue 1. P. 98-101. doi: https://doi.org/10.1016/s0006-291x(02)00631-9

22. Control of Postharvest Diseases of Sweet Cherry with Ethanol and Hot Water / Karabulut O. A., Arslan U., Kuruoglu G., Ozgenc T. // Journal of Phytopathology. 2004. Vol. 152, Issue 5. P. 298-303. doi: https://doi.org/10.1111/j.1439-0434.2004.00844.x

23. Karabulut O. A., Arslan U., Kuruoglu G. Control of Postharvest Diseases of Organically Grown Strawberry with Preharvest Applications of some Food Additives and Postharvest Hot Water Dips // Journal of Phytopathology. 2004. Vol. 152, Issue 4. P. $224-228$. doi: https://doi.org/10.1111/j.1439-0434.2004.00834.x

24. Reduction of Postharvest Decay of Peach and Nectarine Caused by Monilinia laxa Using Hot Water Dipping / Jemric T., Ivic D., Fruk G., Matijas H. S., Cvjetkovic B., Bupic M., Pavkovic B. // Food and Bioprocess Technology. 2010. Vol. 4, Issue 1. P. 149-154. doi: https://doi.org/10.1007/s11947-010-0355-z

25. Effect of yeast antagonist in combination with heat treatment on postharvest blue mold decay and Rhizopus decay of peaches // International Journal of Food Microbiology. 2007. Vol. 115, Issue 1. P. 53-58. doi: https://doi.org/10.1016/j.ijfoodmicro.2006.10.002

26. Investigation of the influence of antimicrobial preparations on the shelf life of broccoli cabbage / Pusik L., Pusik V., Lyubymova N., Bondarenko V., Gaevaya L. // EUREKA: Life Sciences. 2018. Issue 4. P. 13-19. doi: https://doi.org/10.21303/2504-5695.2018.00681

У результаті проведених експериментальних досліджень встановлено, що для поліпшення консистениї̈ при зберіганні кисломолочних напоїв, необхідно забезпечити зв'язування вільної вологи за рахунок застосування натуральних стабілізаторів, загущувачів та речовин, що виконують аналогічну функцію. Серед багатьох апробованих інгредієнтів цієї групи речовин, відібрано для впровадження та надано перевагу використанню стабілізуючих систем на основі природних складових рослинного та тваринного походження. Аналіз інформачійних джерел показує відсутність даних про використання пшеничних висівок у технологіях кисломолочних напоїв. Тому виникає об'єктивна необхідність створення нових видів кисломолочних напоїв, а саме кефірів з використанням пшеничних висівок. Споживання таких функціональних продуктів гарантує усунення недостатнього харчування, поповнення організму необхідими компонентами.

Вивчено вплив пшеничних висівок на якісні показники кисломолочного напою. Встановлено, що кисломолочний напій з пшеничними висівками з мчж 2,5\% за фізико-хімічними показниками відповідає вимогам діючого стандарту ДСТУ 4417:2005. Кефір. Технічні умови. При дослідженні органолептичних показників напою із використанням пшеничних висівож встановлено його чистий кисломолочний смак $і$ запах. В напої з пиеничними висівками зростала загальна сума амінокислот - на 15,08\%, в тому числі незамінних - на 10,57 замінних - на 18,24 \%, Виявлені зміни в амінокислотному складі напою з пшеничними висівками вказують на те, що використання пшеничних висівок при виготовленні кисломолочних напоїв дозволяе підвищити їх харчову та біологічну цінність білкової складової.

Додавання пшеничних висівок не тільки корегує харчову та біологічну цінність кисломолочного продукту, а й дозволяє підвищити його якісні характеристики за рахунок зв'язування вільгої вологи впродовж зберігання

Ключові слова: кисломолочні напої, добавки, пшеничні висівки, амінокислоти, органолептичні показники, фізико-хімічні показники

\section{Introduction}

Modern severe environmental conditions create the urgent need to improve the structure of nutrition of the
UDC 637.1

DOI: $10.15587 / 1729-4061.2018 .140093$

INFLUENCE OF WHEAT BRAN ON QUALITY INDICATORS OF A SOUR MILK BEVERAGE

V. Nagovska

$\mathrm{PhD}$, Associate Professor*

Y. Hach a k

$\mathrm{PhD}$, Associate Professor*

B. G u t y j

Doctor of Veterinary Science, Professor

Department of Pharmacology and Toxicology**

E-mail: bvh@ukr.net

O. B i l y k

$\mathrm{PhD}$, Assistant*

N. S I y v k a

$\mathrm{PhD}$, Associate Professor*

*Department of Technology of milk and milk products**

**Stepan Gzhytskyi National

University of Veterinary Medicine and Biotechologies Lviv Pekarska str., 50, Lviv, Ukraine, 79010 